\title{
INVESTIGATION OF BLACK POPLAR (POPULUS NIGRA L.) PREPARATION AND UTILIZATION FOR ENERGY CONVERSION
}

\author{
Algirdas Jasinskas ${ }^{1}$, Vilma Banioniene ${ }^{1}$, Egle Jotautiene ${ }^{1}$, Imants Ziemelis ${ }^{2}$ \\ ${ }^{1}$ Vytautas Magnus University, Lithuania; ${ }^{2}$ Latvia University of Life Sciences and Technologies, Latvia \\ algirdas.jasinskas@vdu.lt, egle.jotautiene@asu.lt,imants.ziemelis@1lu.lv
}

\begin{abstract}
The research investigations with a short rotation energy plant - black poplar (Populus Nigra L.) have been carried out at the Institute of Agricultural Engineering and Safety of Vytautas Magnus University. A chopper with a conical screw was selected for the energy plants chopping. This type of woody plant choppers is the most appropriate to use because these choppers cut plants by a conical screw with a sharpened outer edge and, therefore, can cut long enough and high quality chaff. The biometric characteristics of black poplar stems and thephysical-mechanical characteristics of the plant chaff were assessed: moisture content, bulk destiny, fall and natural crumble angles, chopped mass fractional composition, ash content and calorific value. The determined bulk destiny of the plant chaff varied from 112.3 to $218.5 \mathrm{~kg} \cdot \mathrm{m}^{-3}$ DM (dry matter). Black poplar chopping quality, characterized by fractional composition, was also determined ,. It was estimated that the largest part of fraction was concentrated on the sieves with a diameter of 8 and $16 \mathrm{~mm}$ holes - from $53.9 \%$ to $71.8 \%$, and very small amount of dust was formed - from 0.04-0.09\%. The research results of the black poplar ash content and calorific value show that the ash content was relatively low and reached only $2.5 \%$. It shows that the chaff of black poplar burns relatively well and, in comparison with other sorts of energy plants, the determined lower calorific value of black poplar chaff dry mass is relatively high $-18.5 \mathrm{MJ} \cdot \mathrm{kg}^{-1}$. The presented research results show that the usage of black poplar for biofuel is justified very well.
\end{abstract}

Keywords: black poplar, biofuel, chaff properties, energy plant.

\section{Introduction}

According to the data of the Statistic Department dated on 2016, forests cover $33.3 \%$ of the entire Lithuanian territory. Through the past years the country forests have increased by $2 \%$ [1]. It is necessary to make adequate woody feedstock availability for the environmental and economic sustainability. Short rotation woody crops are useful to grow because they are renewable energy feedstock for biofuels, bioenergy and bio products that can be strategically placed in the landscape to converse soil and water, recycle nutrients and sequester carbon [2]. Also, usage of short rotation plants as a raw material for bioenergy can reduce the constantly growing demand for wood and its processed products [3]. In some of the world countries as well as in the European countries it has been recognized that genus Populus is the most viable option for all short rotation plantations and is the main breeding subject. The main energetic characteristics of the crops should have: light yields, low production inputs and high energy values to make the production of energy from biomass even more economically efficient and to optimize the environmental benefits [4].

Soil physical characteristics are very important for growing Populus. It was investigated that soil acidity is known to be an important factor influencing the poplar growth [5]. It is recommended to grow poplar on nutrient-rich soils; the soil should have a $\mathrm{pH}$ above 5 [6;7]. Similarly, Boysen and Strobl [8] recommended well-drained soils with continuous water supply, a soil depth of $1 \mathrm{~m}$ and a pH value between 5.5 and 7.5 for poplar cultivation. The role of nitrogen as the main nutrient element to SRC is well described in many scientific publications [9]. Also, there is a number of experiments where different liming materials are used as an object of investigation for some short rotation species.

It is important to measure the physic-mechanical peculiarities of black poplar. The assessment of biomass quality indicators, like chaff, composition of produced chaff fractions, ash content after plant burning, biomass gross calorific value, has been investigated in some EU countries, but there is lack of information and studies on these plants under Lithuanian climate conditions. High burning efficiency depends on the particular chaff quality, thinness.

It is known that a high burning efficiency is produced in furnaces when chaff of the required thinness is used, but this specific area lacks information..

The aim of the presented work is to investigate the biometric, physical-mechanical and thermal characteristics of black poplar preparation and utilization for energy conversion. 


\section{Materials and methods}

The experimental analysis with the selected stems of black poplar was carried out at the experimental basis of the Institute of Agricultural Engineering and Safety of the Vytautas Magnus University. For assessment of the physical - mechanical and biometrical properties of plant stems 20 stems were selected. For short rotation energy crops it is important to evaluate the quality of the cut chopping and the measured cutting length. Black poplar stems of various diameters were used for the research investigations : P.1 $(17 \mathrm{~mm})$, P.2 $(14 \mathrm{~mm})$ and P.3 $(12 \mathrm{~mm})$. The biometrical characteristics of black poplar stems and the physical - mechanical properties of chaff were investigated: such as humidity, bulk destiny, fall and natural crumble angles, chaff thinness (fractional composition), elemental composition, ash content and the colorific value.

\section{Biometric characteristics of black poplar stems}

The mass and humidity of the black poplar stems were estimated according to the standard methodology [10]. The capacity (tones from 1 ha DM) of the stem was determined by cutting the poplars down from each plantation and by weighting the stems. According to the estimated humidity, the capacity of the plants was determined per area unit of dry matter (DM). The full mass of the stem and the mass of $1 \mathrm{~m}$ long lower part of the stem were weighted for investigation of the plant stem mass.

After determination the mass of the $1 \mathrm{~m}$ long part of the stem and after measuring the diameters at both ends, the volume and stem density were calculated [11].

\section{The moisture content of stems}

The moisture content of plants stems was determined in the chemical laboratory according to the standard methodology [10;12]. 3 stems chopped and 3 samples for $200 \mathrm{~g}$ each to determine the moisture content were taken. The moisture of the stem was the ratio between the water amount in the sample and the mass of the sample. The average mass of three stems was estimated and written down.

\section{The destiny of stems}

When the diameter of the stems had already been found, the volume $V_{\mathrm{st}}$ of $1 \mathrm{~m}$ length of the stem and the plot $\mathrm{m}^{2}$ of the stem cross-section were calculated. Since the mass $m_{\mathrm{st}}$ of $1 \mathrm{~m}$ length of the stem was known, the density $\rho_{\mathrm{st}}$ of the stem mass was estimated. When the moisture content of the stems was estimated, the density of each stem and the average density of the dry matter (DM) with the confidence interval of the data dispersion were calculated.

\section{Chopping quality and chaff properties}

The energy plant chopping mechanism can have three types of choppers: drum, disc, and conical. The result of the experiment shows that the conical chopper is the most appropriate to use for energy plants of average maturity and short rotation. The chips in this chopper are being cut by a sharpened outer edge; therefore, this chopper can cut longer chips than other mentioned choppers. The stems of the plants were chopped by the conical screw chopper "Laimet 21 ".

The standard methodology used in Germany and other EU countries has been used for determination of the stem chopping quality [11]. The size of the chopped particles is determined by using a mesh shredder with different mesh holes: $63 \mathrm{~mm}, 45 \mathrm{~mm}, 16 \mathrm{~mm}, 8 \mathrm{~mm}, 3.15 \mathrm{~mm}$ and 1.0 $\mathrm{mm}$. The samples of the chaff (sample weight $3 \mathrm{~kg}$ ) were poured on a set of sieves and shaken for 2 minutes with a sieve shaker. The mass accumulated on each sieve was weighed and the percentage of each fraction was calculated. Every test was repeated 5 times.

\section{Determination of black poplar elemental composition, ash content and calorific value}

The plant chaff elemental composition and ash content were determined in the Lithuanian Energy Institute (LEI) Thermal Equipment Research and Testing Laboratory in accordance with the current Lithuanian and European Union standard methodology using the basic element analyzer Flash 2000 (USA), the ash content test was carried out according to the standard LST EN 14774-1: 2010. T

he calorific value $\left(\mathrm{KJ} \cdot \mathrm{kg}^{-1}\right)$ of oak waste pellets was determined by the calorimeter C 2000 (IKA, Germany) according to the standard methodology (BS EN 14918: 2009). 


\section{Results and discussion}

\section{Biometrical indicators of short rotation plant stems}

The results of the biometric properties of black poplars show that the height of every black poplar stem depends on the width of the stem. When the diameter of black poplar stems was the largest at P.1 $(17 \mathrm{~mm})$, its length reached $3.0 \mathrm{~m}$, and when the diameter of the black poplar was the smallest at P.3 $(12 \mathrm{~mm})$, the height was approximately $30 \%$ smaller and reached only $2.1 \mathrm{~m}$. The length between the largest and smallest black poplar stems differs by $874.33 \mathrm{~mm}$. Table 1 .

Biometrical properties of black poplar stems

\begin{tabular}{|l|c|c|c|}
\hline \multirow{2}{*}{\multicolumn{1}{|c|}{ Properties }} & \multicolumn{3}{|c|}{ Black poplar } \\
\cline { 2 - 4 } & P.1 $(17 \mathrm{~mm})$ & P.2 $(14 \mathrm{~mm})$ & P.3 $(12 \mathrm{~mm})$ \\
\hline Stem height, cm & $299.00 \pm 123.53$ & $257.00 \pm 112.72$ & $212.00 \pm 100.49$ \\
\hline Stem diameter, mm & $17.13 \pm 1.12$ & $14.00 \pm 0.91$ & $11.65 \pm 0.89$ \\
\hline Stem mass of the full length, $\mathrm{g}$ & $607.80 \pm 2.92$ & $339.45 \pm 2.49$ & $165.90 \pm 2.04$ \\
\hline Stem moisture content, \% & $54.42 \pm 0.82$ & $53.78 \pm 0.62$ & $50.93 \pm 0.43$ \\
\hline Density of stem dry matter, $\mathrm{kg} \cdot \mathrm{m}^{-3}$ & $851.42 \pm 86.60$ & $877.32 \pm 76.93$ & $720.30 \pm 66.88$ \\
\hline
\end{tabular}

The analysis of the black poplar stem mass shows that the mass of the largest full length stems was significantly larger P.1 $(17 \mathrm{~mm}) 607.80 \pm 2.92 \mathrm{~g}$. The mass of P.2 $(14 \mathrm{~mm})$ reached $339.45 \pm 2.49 \mathrm{~g}$. The smallest full length of the black poplar stems, P.3 $(12 \mathrm{~mm})$, was approximately 4 times smaller than P.1, twice smaller than P. 2 and reached only $165.90 \pm 2.04 \mathrm{~g}$.

The analysis of the plant stem moisture content shows that the moisture content was slightly larger in the largest black poplar stems, P.1 $(17 \mathrm{~mm})-54.42 \pm 0.82 \%$, smaller at P.2 $(14 \mathrm{~mm})$ $53.78 \pm 0.62$ and the smallest black poplar stems, P.2 $(12 \mathrm{~mm})$, had a moisture content that reached $50.93 \pm 0.43 \%$. The determined density of the stems varied from $851.42 \pm 86.60$ to $720.30 \pm 66.88 \mathrm{~kg} \cdot \mathrm{m}^{-3}$ DM.

\section{Physical-mechanical properties}

The physical-mechanical properties of black poplar stems (moisture content, density, fall $\alpha_{\mathrm{gr}}$ and natural crumble $\alpha_{\mathrm{n}}$ angles) were determined after 3 months of cutting and drying period, and the plant stems were chopped by a conical screw chopper. The test results are presented in Table 2 . The natural crumble angle of the black poplar stem chaff changed from 42 to 39 degrees, whereas the collapse angle - from 63 to 67 degrees. These results can be used to estimate the size of the poplar chaff storages and sites. Moreover, on the basis of the chaff crumble angle, the constructive parameters of storages and walls of the supply to the fireplaces mechanisms can be determined.

Physical-mechanical properties of Black poplar (Populus nigra L.) stem chaff

\begin{tabular}{|c|c|c|c|c|c|c|}
\hline \multirow{2}{*}{$\begin{array}{c}\text { Plant } \\
\text { species }\end{array}$} & $\begin{array}{c}\text { Chaff } \\
\text { moisture } \\
\text { content, \% }\end{array}$ & $\begin{array}{c}\text { Mass, } \\
\mathrm{g}\end{array}$ & $\begin{array}{c}\text { Volume, } \\
\mathrm{m}^{3}\end{array}$ & Density, $\mathrm{kg} \cdot \mathrm{m}^{-3}$ & \multicolumn{2}{c|}{ Flow angles } \\
\cline { 3 - 6 }${ }_{n}{ }^{0}$, & $\alpha_{g r}{ }^{0}$ \\
\hline P.1 $(17 \mathrm{~mm})$ & $\begin{array}{l}34.99 \\
\pm 0.47\end{array}$ & $\begin{array}{c}518.13 \\
\pm 0.13\end{array}$ & 0.003 & $\begin{array}{c}172.71 \pm 01.1 \\
(1122.8 \pm 0.12 \mathrm{DM})\end{array}$ & $\begin{array}{c}42 \\
\pm 4.22\end{array}$ & $\begin{array}{c}67 \\
\pm 6.42\end{array}$ \\
\hline P.2 (14 mm) & $\begin{array}{c}27.48 \\
\pm 0.53\end{array}$ & $\begin{array}{c}282 \\
\pm 0.06\end{array}$ & 0.001 & $\begin{array}{c}282 \pm 0.16 \\
(204.51 \pm 0.20 \mathrm{DM})\end{array}$ & $\begin{array}{c}41 \\
\pm 6.57\end{array}$ & $\begin{array}{c}65 \\
\pm 5.98\end{array}$ \\
\hline P.3 (12 mm) & $\begin{array}{c}25.52 \\
\pm 0.44\end{array}$ & $\begin{array}{c}117.37 \\
\pm 0.03\end{array}$ & 0.001 & $\begin{array}{c}293.42 \pm 0.18 \\
(218.54 \pm 0.25 \mathrm{DM})\end{array}$ & $\begin{array}{c}39 \\
\pm 4.78\end{array}$ & $\begin{array}{c}63 \\
\pm 3.95\end{array}$ \\
\hline
\end{tabular}

Chopping quality of plant stems

The chaff of short rotation plant - black poplar - was used for the research investigations. The plant stem chopping quality and variation of fractions are presented in Fig. 1, Fig. 2 and Fig. 3. 


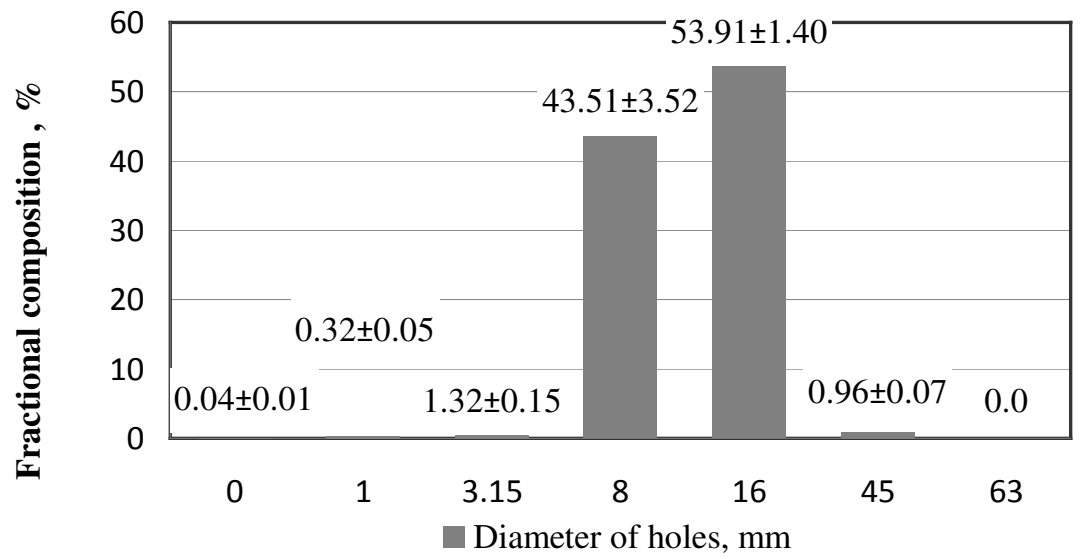

Fig. 1. Dependence of black poplar P.1 (17 mm) chaff fractional composition on hole diameter

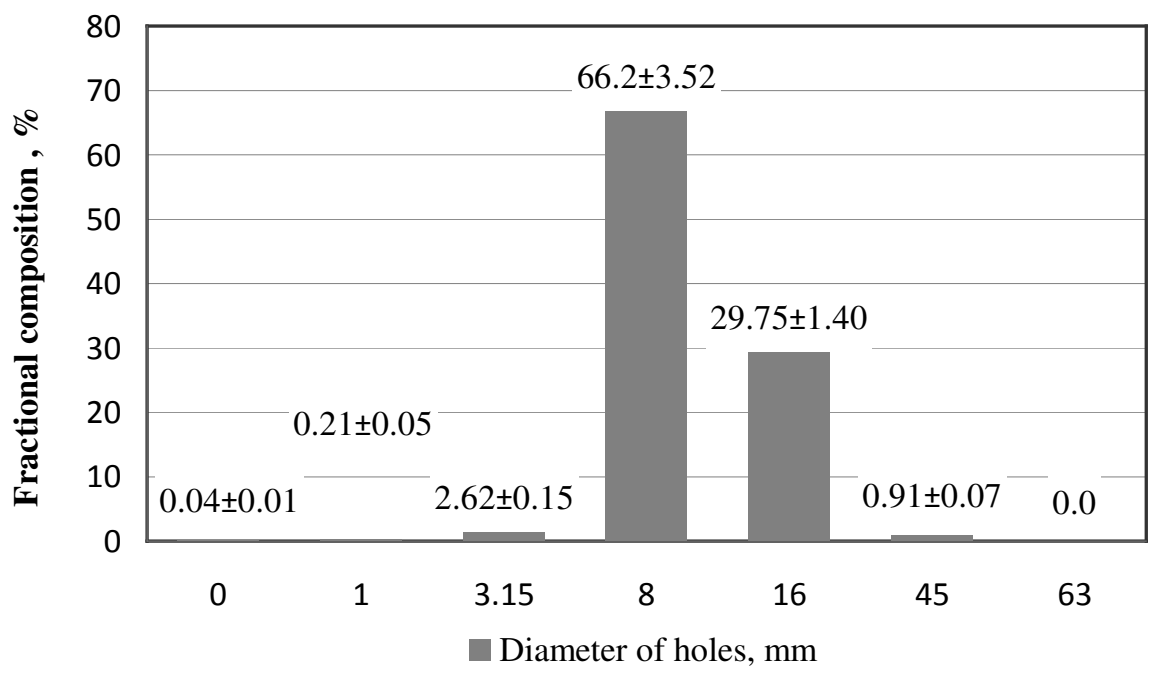

Fig. 2. Dependence of black poplar P.2 (14 mm) chaff fractional composition on hole diameter

The analysis of the black poplar fractional composition (Fig. 1, Fig. 2) has shown that for the poplars with thicker stems (P.1), a larger amount of chaff fraction concentrated on the sieves with the 16-mm-diameter holes (53.9\%); whereas for the poplars with thinner stems (P.2), the largest amount of chaff fraction concentrated on the sieves with the 8-mm-diameter holes $(70.06 \%)$. Also, it was determined that a very small dust amount (from 0.04 to $0.09 \%$ ) and small particles (1.0-3.16 mm size) concentrated on the sieves with the 1.0 -mm-diameter holes (from 0.22 to $0.32 \%$ ).

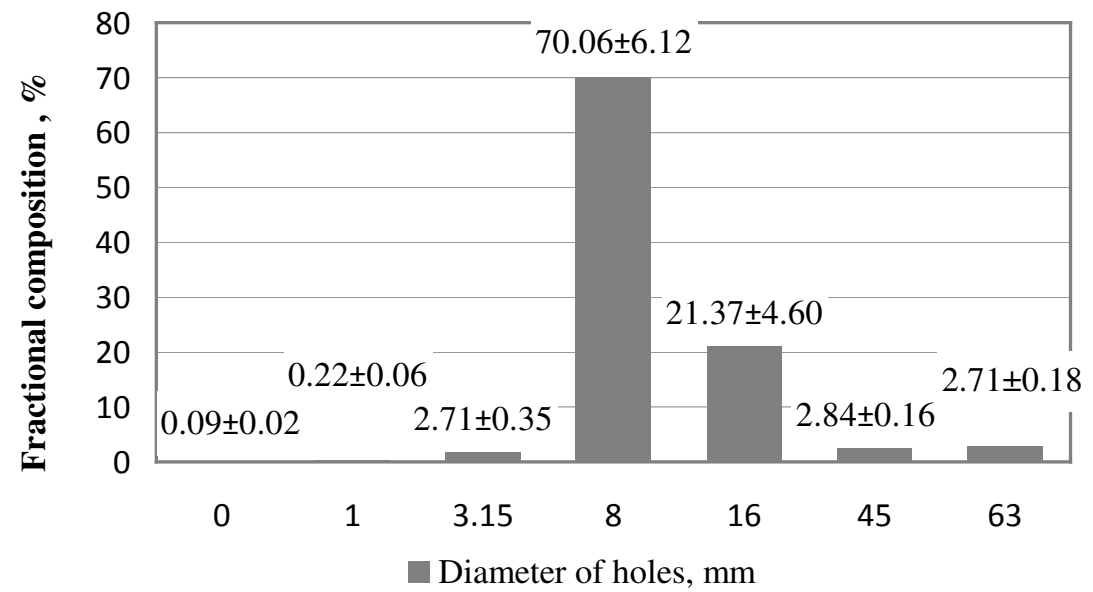

Fig. 3. Dependence of black poplar P.3 (12 mm) chaff fractional composition on hole diameter 


\section{Black poplar quality indicators: elemental composition, ash content and calorific value.}

The research results of the black poplar chaff elemental composition, ash content and the calorific value are presented in Table 3. In the table, the results show that the black poplar chaff elemental composition analysis showed C (carbon) content of $49.67 \%$, O (oxygen) content $42.61 \%, \mathrm{H}$ (hydrogen) content of $5.59 \%$ and other chemicals were in small volumes - $\mathrm{N}$ (nitrogen) content of $0.22 \%$ and $\mathrm{S}$ (sulphur) content of $<0.01 \%$.

Table 3

Plant chaff elemental composition, ash content and calorific value

\begin{tabular}{|l|c|}
\hline \multicolumn{1}{|c|}{ Parameters } & Value, deviation \pm \% \\
\hline $\mathrm{C}$ (carbon) content, \% & $49.06 \pm 1.20$ \\
\hline $\mathrm{H}$ (hydrogen) content, \% & $5.59 \pm 0.44$ \\
\hline $\mathrm{N}$ (nitrogen) content, \% & $0.22 \pm 0.02$ \\
\hline $\mathrm{S}$ ( sulphur) content, \% & $<0.01 \pm 0.00$ \\
\hline $\mathrm{O}$ (oxygen) content, \% & $42.61 \pm 1.90$ \\
\hline Ash content, \% & $2.52 \pm 0.28$ \\
\hline Moisture content, \% & $10.36 \pm 0.07$ \\
\hline Dry biofuel upper calorific value, $\mathrm{MJ} \cdot \mathrm{kg}^{-1}$ & $19.65 \pm 0.29$ \\
\hline Dry biofuel lower calorific value, $\mathrm{MJ} \cdot \mathrm{kg}^{-1}$ & $18.49 \pm 0.33$ \\
\hline
\end{tabular}

\section{Conclusions}

It was investigated that usage of the short rotation energy plant - black poplar (Populus Nigra L.)for biofuel is justified very well; and the chaff prepared by a conical chopper can be used in medium and high power boilers. The quality of the prepared chaff is high enough, and the quality of the chaff delivery and transport systems is guaranteed. After investigation of the chaff fractional compositionit was determined that the largest chaff fraction was concentrated on the sieves with the holes of $8 \mathrm{~mm}$ $(70.06 \%)$ and $16 \mathrm{~mm}(53.91 \%)$ diameter. The research results of the black poplar ash content and calorific value show that the ash content was relatively low and reached only $2.5 \%$. It shows that the chaff of black poplar burns relatively well and, in comparison with other sorts of energy plants, the determined lower calorific value of black poplar chaff dry mass is relatively high $-18.5 \mathrm{MJ} \cdot \mathrm{kg}^{-1}$.

The $3^{\text {rd }}$ growing rotation of the investigated crops is ongoing until 2021, so our next task is to evaluate the longevity as well as the suitability of biomass for other kinds of biofuels, including economical evaluation.

\section{References}

[1] Bioenery Europe, statistics data. [online][16.02.2019] Available at: http://www.biokuras.lt/ dokumentai-ir-statistika-pasaulyje.

[2] Zalesny R.S., Cunningham M.W., Hall R.B., Mirck J., Rockwood D.L, Stanturf J.A., Volk T. Woody biomass from Short Rotation Energy Chrops, USA, 2011. 28 p. [online][16.02.2019] Available at:

http://citeseerx.ist.psu.edu/viewdoc/download?doi $=10.1 .1 .431 .7376 \&$ rep $=$ rep1\&type $=$ pdf.

[3] Englund O., Berndes G., Fredrikson F., Dimitriou I. Meeting sustainability requirements for SRC bioenergy: usefulness of existing tools, responsibilities of involved stakeholders, and recommendations for further developments. Bioenergy Res 5: pp. 606-620.

[4] Scolz V., Ehlert D., Hoffmann T., Kern J., Pecenka R. Cultivation, Harvest and Storage of Short Rotation Coppice - Long-Term Field Trials, Environmental Effects and Optimisation Potentials in Germany. [online][16.02.2019] Available at: http://dergipark.gov.tr/download/article-file/118900.

[5] Leuschner C., Hertel D. Fine root biomass of temperate forests in relation to soil acidity and fertility, climate, age and species. Progress in Botany, 2003, vol. 64, pp. 405-438.

[6] Bergstedt A.E. Dyrkning af poppel [Management of poplar]. Statens forstlige Forsøgsvæsen, Denmar, 1981. 
[7] Ericsson T., Lindsjo I. The influence of $\mathrm{pH}$ on growth and nutrition of some energy forest species. Swedish University of Agricultural Sciences, Energy Forestry Project (EFP), Technical Report No 11, Uppsala, 1981.

[8] Boysen B., Strobl S. A grower's guide to hybrid poplar. Ministry of Natural Resources, Ontari, 1991.

[9] Cooke J. E., Martin T.A., Davis J.M. Short-term physiological and developmental responses to nitrogen availability in hybrid poplar. New Phyt., 2005. 41 p.

[10] Park B.B., Yanai R.D., Sahm J.M., Lee D.K., Abrahamson L.P. Wood ash effects on plant and soil in a willow bioenergy plantation. Biomass Bioenergy, 2005, 28(4), pp. 355-365.

[11] Jasinskas A., Simonavičiūtė R., Šiaudinis G., Liaudanskienė I., Antanaitis Š., Arak M., Olt J. The assessment of common mugwort (Artemisia vulgaris L.) and cup plant (Silphium perfoliatum L.) productivity and technological preparation for solid biofuel // Žemdirbyste = Agriculture , 2014, vol. 101 (1), pp. 19-26.

[12] Šiaudinis G., Jasinskas A., Šarauskis E., Steponavičius D., Karčiauskienė D., Liaudanskienė I. The assessment of Virginia mallow (Sida hermaphrodita Rusby) and cup plant (Silphium perfoliatum L.) productivity, physico-mechanical properties and energy expenses. Energy, 2015, vol. 93(1), pp. 606-612. 